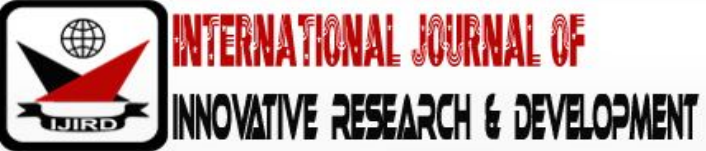

ISSN 2278 - 0211 (Online)

\section{Influence of Teachers' Depersonalization on Implementation of Secondary School Curriculum in Longido and Monduli Districts, Arusha, Tanzania}

Christina Elisante Mnjokava
Ph. D. Candidate, Department of Education, Mwenge Catholic University, Tanzania
Dr. Evans Ogoti Okendo
Senior Lecturer, Department of Education, Mwenge Catholic University, Tanzania
Dr. Paschal Wambiya
Senior Lecturer, Department of Education, Mwenge Catholic University, Tanzania

\begin{abstract}
:
Teachers play an important role in the implementation of secondary school curriculum. However, implementation of secondary school curriculum has not been effective. The study was guided by the persistent burnout and curriculum implementation theories. The study adopted mixed methods approach and used the concurrent triangulation research design. The target population for this study was 806 respondents from which a sample of 243 was selected using the Central Limit Theorem. Questionnaires were used to collect quantitative data from secondary school teachers whereas interview guides were used to collect qualitative data from school heads and education officers. Validity was established through expert judgment whereas reliability was determined using test retest technique and reliability index, $r=0.853$, was obtained using Cronbach Alpha Method. Credibility of qualitative data was ascertained by involving multiple analysis, whereas dependability was established through detailed reporting of the researcher process. Qualitative data were analyzed thematically along the research questions and presented in narrative forms whereas quantitative data were analyzed using descriptive statistics and inferentially using ANOVA and presented in tables and charts. The study established that teachers' depersonalization influence implementation of secondary school curriculum. Thus, the study recommends that school management and Ministry of Education need to devise ways of motivating teachers by providing incentives, instructional resources and physical facilities. Teachers need to develop positive self-esteem, attitude and positive perception towards oneself. Teachers ought to learn to avoid aggressive acts and adhere to ethical standards of handling professional challenges in education. The Ministry of Education needs to hire more teachers to reduce workload which create burnout amongst teachers. The Ministry of Education ought to conduct seminars and workshops for teachers and to remind them of their duties despite the heavy workload.
\end{abstract}

Keywords: Teachers' depersonalization, teacher burnout, implementation of secondary school curriculum.

\section{Introduction}

Implementation of secondary school curriculum entails putting into practice the officially prescribed courses of study, syllabuses and subjects. According to Cohen and Hill (2012), the process of curriculum implementation involves helping the learner to acquire knowledge or experience. It is vital to note that implementation of secondary school curriculum takes place as a strategy to enable the learner to acquire experiences, knowledge, skills, ideas and attitudes that are aimed at enabling the same learner to function effectively in a society (Beane, 2012). Curriculum, as an academic plan, is the way content is designed and developed. The process includes the structure, organization, and balance of the materials. Implementation of secondary school curriculum therefore refers to how the planned or officially designed course of study is translated by the teacher from syllabuses into schemes of work and lesson plans to be delivered to learners (Beane, 2012). Teachers play a critical role in the implementation of curriculum.

Cognizant of this assertion, Cohen and Hill (2012) further posit that, in London, teachers are considered to have a critical role for the actualization of the ideas in the secondary school curriculum. Curriculum change, however, standing alone is not adequate for providing high quality of education rather there is a need for good implementers of those developed curriculums. According to Cohen and Hill (2012), teachers are the principal actors who transfer all the theoretical information into real classroom setting, whenever there is an implementation of a new curriculum, the issue of whether secondary school teachers are facing problems in the process of implementation or not are triggered. In curriculum implementation, both personal and environmental factors of teachers, as secondary school curriculum implementers, are effective. However, an observation as an educator is that teachers are still using the traditional method 
of teaching, where a teacher is regarded as the only source of information and the learners as the vessels that need to be filled with knowledge or learning materials.

Morris (2012) indicates that for teachers to be self-motivated and committed to their objectives, the mutual relationship amongst teachers should be promoted, all stakeholders should be involved in planning the curriculum, and there should be opportunities for growth and more innovative and effective teaching methods. However, teachers are often confronted with numerous challenges such as burnouts and depersonalization thus bring their past experience into classroom settings which eventually impact on how students learn and develop. Depersonalization represents the interpersonal dimension of burnout. It refers to a negative and detached response to others. Depersonalization is usually a common response for individuals experiencing emotional exhaustion; and eventually turns into dehumanization of others, particularly in the work environment. Depersonalization consists of cynical or negative attitudes about ones' clients. This dehumanizing perception of others can lead staff members to view their clients as deserving of their troubles (Ryan, 2014). Depersonalization is described as a defensive coping strategy, where an individual limit one's own involvement with others and creates a psychological distance. Through such response the individual tries to create an emotional buffer between oneself and the imposed job demand (Cordes \& Dougherty, 2013). It is also characterized as a negative, cynical or excessively detached response to other organizational members; it thus represents the interpersonal component of burnout (Shirom, 2003). Empirical evidence has shown that depersonalization has significant dysfunctional ramifications, which implies substantial costs for organization and its members.

For instance, it leads to absenteeism, reduced job satisfaction, reduced commitment and teacher turnover intentions (Lee, Lim, Yang \& Lee, 2011). This implies that, as a long-term consequence of prolonged exposure to certain job demands; depersonalization, which originally refers to distancing oneself emotionally from service recipients, it is a state of detachment from students, parents, and other teachers that disturbs a teacher's personal and professional life and a reduced sense of personal accomplishment which is described as a person's negative self-evaluation regarding his or her job performance. Vandenberghe and Huberman (2011) assert that symptoms of teacher burnout are in four separate forms, namely physical, emotional, mental, and behavioral. Vandenberghe and Huberman (2011) further assert that, physically a burnout teacher may suffer from chronic fatigue, frequent headaches, nausea and weariness.

In India, Parker, Martin, Colmar and Liem (2012) assert that depersonalization can also result in decreased selfworth, which in turn leads to reduced desire and ability to accomplish job-related tasks and assignments. In particular, depersonalization may be expressed through poor attitudes towards students and the work environment. Parker et al (2012) further assert that teachers may be at greater risk for depersonalization because their daily work life often includes large doses of isolation from their professional peers. While teachers do interact with others on a regular basis throughout the workday, the majority of such interactions are with students, and not with other teachers or professional staff members who might better understand the demands teachers face (Parker et al, 2012). While depersonalization may act as some protection for teachers, it also may encourage isolation, strengthening the risk for burnout. Teachers suffering from depersonalization lose the desire and faith in their ability to do well in their jobs (Nash, 2010). They tend to develop cynical attitudes toward students that can result in negative behaviors and attitudes including sarcasm, making derogatory comments, ignoring students' needs, and an overall breakdown in communication. However, severe and frequent tantrums that persist into the secondary school and school-age years are cause for concern as it impacts on teachers' academic performance. In keeping with these assertions, Adem and Melek (2010) conducted a study to measure the burnout and job satisfaction levels of academicians and to explore the relationships between burnout and job satisfaction among academicians in Turkey which revealed that the general burnout, emotional exhaustion and depersonalization scores increase as "the recognition academics get for good work" satisfaction scores decrease.

In most countries in Sub-Saharan Africa, aggressive teachers may "invite" or encourage peer victimization through peer provocation like upsetting other teachers and initiating fights (Bell \& Wolfe, 2014). In contrast, in a study conducted in Morocco, Shaw and Emery (2015) posited that the shy, timid nature of socially withdrawn teachers may elicit the social perception of being easy targets. They may evoke victimization precisely because they present themselves as physically and emotionally weak and unlikely to retaliate (Little \& Garber, 2015). This view is consistent with Olweus's (2014) characterization of socially withdrawn teachers and with Perry et al (2014) research on "passive victims". In South Africa, De Witt (2013) indicated that, although socially withdrawn teachers may have difficulties forming large numbers of friendships, it is nevertheless the case that withdrawn teachers and young adolescents are as likely as their typical agemates to have at least one mutual and stable best friend.

In Kenya, it is nevertheless the case that socially withdrawn teachers do differ from their peers on other dimensions of friendship (Okoth, 2011). Moreover, the best friends of extremely withdrawn teachers and young adolescents are more likely to be socially withdrawn and victimized than are the mutual best friends of non-withdrawn teachers (Rubin et al, 2012). Thus, many socially withdrawn teachers appear to be involved in friendships with other teachers who are experiencing similar psychosocial difficulties.

Taken together, these findings suggest that withdrawn teachers experience increased motivation to engage others in social interaction when the social landscape becomes "kinder" and "gentler. In Longido and Monduli Districts in Tanzania, given that socially withdrawn teachers and young adolescents often experience peer rejection and victimization, it is not surprising that they feel and think poorly of themselves (Wilson, 2011). Moreover, as noted above, the social initiations of socially withdrawn teachers often result in peer noncompliance despite the fact that these initiations and requests are less likely than are those of non-withdrawn teachers to require carrying out action that involves both effort and mobility (Wilson, 2011). However, Wilson (2011) has not indicated how such failures to obtain peer compliance and collegiality with peers predict their academic performance in internal and national examinations; a research gap which this study sought to fill. 


\subsection{Statement of the Problem}

Teachers play an important role in the implementation of secondary school curriculum. Teachers ensure that secondary school syllabus is covered and students register impressive grades in internal and national examinations and thus become responsible members of society. However, in Longido and Monduli Districts in Arusha Region of Tanzania, implementation of secondary school curriculum has not been effective. As stated in the background, syllabus coverage is still inadequate and students' performance dismal (Bakker \& Bal, 2010). For example, in 2016, many students registered a drop of 13.9\% in Tanzania National Examinations (National Examinations Council of Tanzania, 2017). In the same vein, teachers, as curriculum implementers, are ever confronted with stressful situations. According to Bakker and Bal (2010), there is habitual patterns of teacher burnout, that is, manifestations of depersonalization due to heavy workload, pressures to ensure that students pass and fear of being sacked if the students fail the national examination. Despite these assertions, few empirical studies have established the causal link between teacher burnout and implementation of secondary school curriculum. In other words, studies have to interrogate the extent to which teachers' depersonalization influence the implementation of secondary school curriculum.

\subsection{Research Questions}

What is the influence of teachers' depersonalization on implementation of secondary school curriculum in Longido and Monduli districts in Arusha Region?

\subsection{Hypothesis}

There is no significant influence of teachers' depersonalization on implementation of secondary school curriculum in Longido and Monduli districts in Arusha Region.

\subsection{Theoretical Framework: The Persistent Burnout Theory}

This study was guided by the Persistent Burnout Theory which was postulated by Jameson (2015). This theory proposes that burnout either is caused by cessation of chronic stress or begins during the period of stress. Persistent theory attempts to provide an explanation on how burnout can bring impacts to teachers on curriculum implementation in secondary school education. Pajares and Schunk (2010) state that, while striving to complete a challenging task or difficult goals, the individuals with high self-efficacy may face failures or setbacks, not give up rather, strive to develop a higher amount of knowledge and increase their effort in order to overcome their failures and setbacks. This theory focuses on a multi-dimensional reason for behavior rather than one single factor. That is why is more helpful in understanding motivation and performance in various kinds of tasks and situations.

In the context of this study, one of the most major and chief reasons that results in the general practitioners' ambiguity and distress over stressors and bring about intolerance and fatigue in them is professional exhaustion or burnout. On the other hand, the theory underscores the fact that teacher burnout can lead to deterioration in the quality of care or service provided by the staff. It appears also to be a factor in job turnover, absenteeism and low morale. Furthermore, burnout seems to correlate with various self-reported indices of personal distress, including physical exhaustion, insomnia, increased use of alcohol and drugs, and marital and family problems. In other words, teachers' depersonalization influence teachers' ability for syllabus coverage and enhance poor students' academic performance. According to this theory, there should be approaches that offer service to provider ways of working that focus on strengths, abilities and potential rather than problems, deficits and pathologies (GlenMaye, 2010; Saleebey, 2010).

School of Social Welfare and others have been developing and testing the strengths perspective (Cohen, 2011; Rapp, 2011). Saleebey (2010) suggests is not a model of practice but rather a "collation of principles, ideas and techniques. The theory states that people are often doing amazingly well, the best they can at the time, given the difficulties they face and the known resources available to them. This make them to survive to this point - certainly, not without pain - but with ideas, wills, hopes, skills and with other people, all of which need to understand and appreciate in order to help. Weick (2010) suggests that, "every person has an inherent power that may be characterized as life force, transformational capacity, life energy, spirituality, regenerative potential, and healing power. This is a potent form of knowledge that can guide a personal and social transformation. This power also means that people "possess the inherent capacity to learn, grow and change (Kisthardt, 2011). Saleebey (2010) suggests that individuals and groups "have vast, often untapped and frequently unappreciated reservoirs of physical, emotional, cognitive and interpersonal. People are recognized as having many strengths and the capacity to continue to learn, grow and change. The focus of intervention is on the strengths and aspirations of the people we work with. Communities and social environments are seen as being full of resources. Service providers collaborate with the people they work with. Interventions are based on self-determination. Problems are seen as the result of interactions between individuals, organizations or structures rather than deficits within individuals, organizations or structures.

People are often doing amazingly well, the best they can at the time given the difficulties they face and the known resources available to them. People have survived to this point- certainly, not without pain- but with ideas, will, hopes, skills and other people, all of which we need to understand and appreciate in order to help. Change can only happen when you collaborate with other peoples' aspirations, perceptions, and strength and when you firmly believe in them. According to Cohen (2011), these approaches tend to focus on individualistic rather than social environmental explanations of human problems. Problems are seen as the result of interactions between individuals, organizations or structures. Problems are frequently the result of interactions between people, organizations or structures (Sullivan \& Rapp, 2010).

By focusing on how the interactions contribute to the situation, as well as concentrating on peoples' strengths, it is possible to avoid blaming the victim (Saleebey, 2010). Their interest and motivation in mastering the task will drive them 
to succeed in their difficult, and that problems are there to be solved and challenges are part of once life. Therefore, we cannot run away from the challenges but rather solve them and move forward for the approachable performance. People are recognized as having many strengths and the capacity to continue to learn, grow and change. The rationale of using this theory in this study was that it supports the fact, that when an individual such as a teacher face difficulties or challenges, he or she cannot perform in his or her workplace.

\section{Literature Review}

Depersonalization represents the interpersonal dimension of burnout. It refers to a negative and detached response to others. Depersonalization is usually a common response for individuals experiencing emotional exhaustion; and eventually turns into dehumanization of others, particularly in the work environment. Depersonalization consists of cynical or negative attitudes about ones' clients. This dehumanizing perception of others can lead staff members to view their clients as deserving of their troubles (Ryan, 2014). Among these three characteristics of burnout, depersonalization remains relatively less understood (Haudebert, Mulki \& Fornier, 2011). Depersonalization is described as a defensive coping strategy, where an individual limit one's own involvement with others and creates a psychological distance. Through such response the individual tries to create an emotional buffer between oneself and the imposed job demand (Cordes \& Dougherty, 2013). It is also characterized as a negative, cynical or excessively detached response to other organizational members; it thus, represents the interpersonal component of burnout (Shirom, 2003).

Empirical evidence has shown that depersonalization has significant dysfunctional ramifications, which implies substantial costs for both the organization and its members. For instance, it leads to absenteeism, reduced job satisfaction, reduced commitment and turnover intentions (Lee, Lim, Yang \& Lee, 2011). This implies that, as a long-term consequence of prolonged exposure to certain job demands; depersonalization, which originally refers to distancing oneself emotionally from service recipients, it is a state of detachment from students, parents, and other teachers that disturbs a teacher's personal and professional life and a reduced sense of personal accomplishment which is described as a person's negative self-evaluation regarding his or her job performance. Vandenberghe and Huberman (2011) assert that symptoms of teacher burnout in four separate forms, namely physical, emotional, mental, and behavioral.

Vandenberghe and Huberman (2011) further assert that, physically a burnout teacher may suffer from chronic fatigue, frequent headaches, nausea and weariness. According to reeves (2012), depersonalization refers to a reaction to stress resulting in a desire to be left alone and to have no personal interaction. In India, Parker, Martin, Colmar and Liem (2012) assert that depersonalization can also result in decreased self-worth, which in turn leads to reduced desire and ability to accomplish job-related tasks and assignments. In particular, depersonalization may be expressed through poor attitudes towards students and the work environment. Parker et al (2012) further assert that teachers may be at greater risk for depersonalization because their daily work life often includes large doses of isolation from their professional peers. Teachers suffering from depersonalization lose the desire and faith in their ability to do well in their jobs (Nash, 2010). They tend to develop cynical attitudes toward students that can result in negative behaviors and attitudes including sarcasm, making derogatory comments, ignoring students' needs, and an overall breakdown in communication. Gaylord et al (2013) posited that when socially withdrawn teachers do interact with peers, they appear to be less socially competent than typical teachers. For example, in an observational study conducted in Germany, Stewart and Rubin (2014) found that socially withdrawn teachers pursued lower-cost social goals and fewer high-cost social goals, and that their attempts to meet their social goals were less likely to succeed than those of their non-withdrawn age-mates.

In recent years, researchers have also begun to explore the underlying meanings and consequences of different subtypes of observed socially withdrawn and solitary behaviors. As noted above, reticent behavior is considered a behavioral expression of a social approach-avoidance conflict and includes the prolonged watching of other teachers without accompanying play and being unoccupied (Coplan et al, 2011). Henderson et al (2014) speculated that for some shy teachers, solitary-passive behavior may serve as a strategy for coping with feelings of social unease. That is, having learned early that the expression of socially reticent behavior elicits peer rejection and victimization, some socially anxious teachers may mask their social qualms by expressing quite constructive and exploratory activity among peers. Furthermore, results from several recent studies have suggested that solitary-passive behavior in secondary schools may, like reticence, be a liability, especially for boys (Coplan et al, 2011, Nelson et al, 2011).

A longitudinal study conducted by Gorman-Smith and Tolan (2012) in Austria revealed that when socially withdrawn teachers attempt to meet their social goals in the company of their peers, they are more likely to directly experience peer neglect and rejection than their more sociable age-mates. Relatedly, it is also well known that socially withdrawn teachers are actively disliked by their peers (Gazelle \& Ladd, 2010; Hart et al, 2010, Ladd, 2011). In fact, social withdrawal is one of the strongest correlates and consequences of peer rejection during middle childhood and adolescence. A psychological model of how stress leads to burnout describes it as a syndrome resulting from teachers' inability to protect themselves against threats to their self-esteem and well-being (Kyriacou \& Sutcliffe, 2011). In this model, teachers' coping mechanisms are activated to deal with demands. When those coping mechanisms fail to stem the demands then stress increases and threatens the teachers' mental and physical well-being ultimately leading to teachers quitting or burning out. Because many of the conditions which determine teacher effectiveness lie outside of their control and because a high level of continual alertness is required, teaching is a high stress job. Burnouts remain in teaching as "strong insensitive" who are able to cope with the debilitating problems faced by their students and the negative conditions of work in dysfunctional bureaucracies because they no longer take their failures as a sign of any personal inadequacies. While work appears as a major source of stress for working people, teachers appear to experience more stress through work than non-teachers" (Cox \& Brockley, 2014). 
In-depth studies have established a clear linkage between prolonged stress and burnout (Blasé, 2013). At the other extreme from the strong insensitive, those who stay in teaching after experiencing burnout are the idealists who are significantly more likely to leave teaching (Miech \& Elder, 2011). The explanation for the departure of idealists is that because they are deeply committed to serving children they are more easily frustrated by the working conditions in dysfunctional school bureaucracies which prevent them from doing what they deem best in the teaching of their students. In 1963 the Milwaukee Intern Program became the model for the National Teacher Corps. In the ten years (1963-1972) of the Corps' existence approximately 100,000 college graduates with high GPAs were prepared nationally for urban teaching. These were idealistic young, white college graduates who set out to "find" themselves by "saving" diverse children in poverty. When they actually encountered the realities of how teachers have to struggle against their school bureaucracies in order to serve children, over 95 percent of them quit in five years or less (Corwin, 2013).

Since this was the largest, longest study ever done in teacher education the notion that altruism can be the motivation of teachers serving diverse children in poverty should be problematic. The average length of a teaching career in the United States is now down to eleven years (Stephens, 2011). One quarter of all beginning teachers leave teaching within four years (Benner, 2010). The length of an urban teaching career is even less since fifty percent of beginners leave in five years or less (Rowan et al, 2012). But teachers who leave have less of a negative impact on schools and students than those who burn out but remain in teaching.

It has long been established that burnouts for who remain use significantly less task-oriented behavior, that is, less hands-on and active learning, and provide fewer positive reinforcements to their students (Koon, 2012). They also have negative effects on student performance (Young, 2016). The research supports the contention that stress affects teachers' effectiveness with students (Blasé, 2013). When teachers feel good about their work student achievement rises (Black, 2011). The persistent and pervasive nature of teacher stress studies makes it clear that teaching has become a high stress occupation. It is argued that peers reject socially withdrawn teachers because their demeanor runs contrary to agespecific norms and expectations for social interaction and relationship- and group-involvement (Rubin et al, 2012). Furthermore, researchers have argued that atypical behavior becomes more salient to the peer group with increased age; this may explain why the association between social withdrawal and peer rejection steadily increases with age (Ladd, 2011).

Teachers who are victimized experience repeated and consistent physical and verbal abuse from their peers and classmates. Given the reserved and quiescent demeanor of many socially withdrawn teachers and given that they often attempt to avoid social company to begin with, one might expect that they would be protected from a bullying experience. Significant associations have also been revealed between social anxiety and victimization during later adolescence (Grills \& Ollendick, 2012). In keeping with these assertions, Adem and Melek (2010) conducted a study to measure the burnout and job satisfaction levels of academicians and to explore the relationships between burnout and job satisfaction among academicians in Turkey which revealed that the general burnout, emotional exhaustion and depersonalization scores increase as "the recognition academics get for good work" satisfaction scores decrease. However, burnout sub dimensions' scores were found to increase as the "the amount of variety in academics' job" satisfaction scores decrease.

In most countries in Sub-Saharan Africa, aggressive teachers may "invite" or encourage peer victimization through peer provocation like upsetting other teachers and initiating fights (Bell \& Wolfe, 2014). In contrast, in a study conducted in Morocco, Shaw and Emery (2015) posited that the shy, timid nature of socially withdrawn teachers may elicit the social perception of being easy targets. They may evoke victimization precisely because they present themselves as physically and emotionally weak and unlikely to retaliate (Little \& Garber, 2015). This view is consistent with Olweus's (2014) characterization of socially withdrawn teachers and with Perry et al (2014) research on "passive victims".

Because social withdrawal and avoidance are strategies often used to cope with peer victimization, a transactional cycle may exist whereby the initially withdrawn child is victimized, which in turn increases his/ her withdrawal from social company and subsequent victimization and poor academic performance (Eisenberg et al, 2012, Gazelle \& Rudolph, 2014). In another study in Namibia, Evy, Louw and Horst (2011) conducted an exploratory on the role of extrinsic and intrinsic factors in determining job satisfaction among urban secondary schools. A sample of 337 respondents randomly was selected from 17 government schools. Results revealed significant levels of dissatisfaction. The study also showed a significant correlation between levels of burnout and job satisfaction particularly with regard emotional exhaustion and depersonalisation. In South Africa, De Witt (2013) indicated that, although socially withdrawn teachers may have difficulties forming large numbers of friendships, it is nevertheless the case that withdrawn teachers and young adolescents are as likely as their typical age-mates to have at least one mutual and stable best friend.

De Witt (2013), for example, found that approximately $65 \%$ of socially withdrawn 10 -year-olds had a mutual best friendship, and approximately $70 \%$ of these best friendships were maintained across the academic year; these friendshipinvolvement and -stability percentages were nearly identical to those of non-withdrawn 10-year-olds. Thus, despite their difficulties in the larger peer group, withdrawn teachers do appear able to form and maintain close dyadic relationships within the school milieu. In Kenya, it is nevertheless the case that socially withdrawn teachers do differ from their peers on other dimensions of friendship (Okoth, 2011). Moreover, the best friends of extremely withdrawn teachers and young adolescents are more likely to be socially withdrawn and victimized than are the mutual best friends of non-withdrawn teachers (Rubin et al, 2012). Thus, many socially withdrawn teachers and young adolescents appear to be involved in friendships with other teachers who are experiencing similar psychosocial difficulties.

Amongst secondary school teachers in Kenya, the friendships of socially withdrawn teachers and young adolescents also tend to be relatively poor in relationship quality which in the long run impact on their academic performance. Mwangi (2012) found that withdrawn young adolescents rated their best friendships as lacking in 
helpfulness, guidance, and intimate disclosure; the best friends of these withdrawn young adolescents rated their friendships as involving less fun and help and guidance than did the best friends of non-withdrawn young adolescents.

Friendlessness, friendship instability, and exclusion and victimization by peers were significant predictors of the trajectory of increased social withdrawal over the four-year period (Okoth, 2011). Decreases in social withdrawal were evident for those young adolescents who experienced decreases in rejection and victimization as they made the transition from elementary to secondary schools. In many ways, this finding is consistent with those of Wilson (2011) who reported that when anxious-solitary young teachers experienced less peer exclusion they displayed an increase in their students' performance. Taken together, these findings suggest that withdrawn teachers experience increased motivation to engage others in social interaction when the social landscape becomes "kinder" and "gentler.

In Arusha, given that socially withdrawn teachers and young adolescents often experience peer rejection and victimization, it is not surprising that they feel and think poorly of themselves (Wilson, 2011). Moreover, as noted above, the social initiations of socially withdrawn teachers often result in peer noncompliance despite the fact that these initiations and requests are less likely than are those of non-withdrawn teachers to require carrying out action that involves both effort and mobility (Wilson, 2011). However, Wilson (2011) has not indicated how such failures to obtain peer compliance and collegiality with peers predict their academic performance in internal and national examinations.

\section{Research Methodology}

The study adopted mixed methods approach and used the concurrent triangulation research design. The target population for this study was 806 respondents from which a sample of 243 was selected using the Central Limit Theorem. Questionnaires were used to collect quantitative data from secondary school teachers whereas interview guides were used to collect qualitative data from school heads and education officers. Both probability and non-probability sampling procedures were used to select participants of the study. The study utilized questionnaires, interview guide, and document analysis guide for data collection Validity was established through expert judgment whereas reliability was determined using test retest technique and reliability was obtained using Cronbach Alpha Method. Credibility of qualitative data was ascertained by involving multiple analysts, whereas dependability was established through detailed reporting of the research process. Qualitative data were analyzed thematically along the research questions and presented in narrative forms whereas quantitative data were analyzed using descriptive statistics and inferentially using ANOVA and presented in tables.

\section{Discussions of the Findings}

4.1. Teachers' Depersonalization and Implementation of Secondary School Curriculum

The study sought to find out the influence of teachers' depersonalization on implementation of secondary school curriculum. Descriptive data was collected from secondary school teachers and results are shown in Table 1;

\begin{tabular}{|c|c|c|c|c|c|c|c|}
\hline Test Items & SA & A & U & D & SD & Mean & St.D \\
\hline & $\mathbf{\%}$ & $\mathbf{\%}$ & $\mathbf{\%}$ & $\mathbf{\%}$ & $\mathbf{\%}$ & & \\
\hline $\begin{array}{c}\text { Teachers are always hostile towards } \\
\text { students which has negatively affected } \\
\text { syllabus coverage }\end{array}$ & 80.5 & 8.5 & 1.5 & 5.5 & 4.0 & 4.834 & 1.059 \\
\hline $\begin{array}{c}\text { Teachers' frequent hostility towards } \\
\text { students has lowered their academic } \\
\text { performance }\end{array}$ & 78.5 & 14.5 & 2.5 & 3.0 & 1.5 & 4.714 & 1.033 \\
\hline $\begin{array}{c}\text { Teachers do withdraw from relationships } \\
\text { whenever they are stressed and has } \\
\text { impacted on syllabus coverage }\end{array}$ & 69.5 & 12.0 & 2.0 & 10.0 & 6.5 & 4.174 & 0.915 \\
\hline $\begin{array}{c}\text { Teachers' withdrawal from friendships has } \\
\text { caused secondary school students' dismal } \\
\text { performance }\end{array}$ & 74.5 & 17.0 & 2.5 & 3.5 & 2.5 & 4.474 & 0.980 \\
\hline $\begin{array}{c}\text { Teachers rarely sympathize with their } \\
\text { students which has negatively affected } \\
\text { syllabus coverage }\end{array}$ & 67.0 & 11.5 & 5.5 & 8.5 & 7.0 & 4.024 & 0.882 \\
\hline $\begin{array}{c}\text { Teachers' unsympathetic attitude towards } \\
\text { students has made them register low } \\
\text { grades }\end{array}$ & 75.0 & 10.5 & 2.5 & 9.0 & 3.5 & 4.504 & 0.987 \\
\hline
\end{tabular}

Table 1: Teachers' Views on the Influence of Depersonalization on Implementation of Secondary School Curriculum

Table 1 reveals that majority, 184(80.5\%) strongly agreed with the view that teachers are always hostile towards students which has negatively affected syllabus coverage as did $19(8.5 \%)$ of the teachers who agreed. However, only a paltry $3(1.5 \%)$ of the teachers were undecided, $13(5.5 \%)$ of the teachers disagreed whereas $9(4.0 \%)$ of strongly disagreed. On average, these findings generated a mean of $\mathrm{M}=4.834$, Std. Deviation $=1.059$. The study also found out that majority, $179(78.5 \%)$ strongly agreed with the view that teachers' frequent hostility towards students has lowered their academic 
performance. At the sametime 33(14.5\%) of the teachers agreed. However, $6(2.5 \%)$ of the teachers were undecided, $7(3.0 \%)$ of the teachers disagreed whereas $3(1.5 \%)$ of the teachers strongly disagreed. On average, these findings generated a mean of $\mathrm{M}=4.714$, Std. Deviation $=1.033$. These findings further support the assertions of Parker et al (2012) that teachers suffering from depersonalization are easily angered, annoyed or irritated, frequent temper tantrums, argues with adults, refuse to obey rules, seem to deliberately try to annoy or aggravate others, low self-esteem, low frustration threshold and seeks to blame others for any misfortunes or misdeeds. In keeping with these assertions, these findings support the findings of a study conducted in Turkey by Adem and Melek (2010) which established that the general burnout, emotional exhaustion and depersonalization scores increase as the recognition academics get for good work satisfaction scores decrease. This is indicative of the fact that depersonalization consists of cynical or negative attitudes about ones' clients. This dehumanizing perception of others can lead staff members to view their clients as deserving of their troubles. Breath

The study also revealed that majority, 158(69.5\%) strongly agreed with the view that teachers do withdraw from relationships whenever they are stressed and has impacted on syllabus coverage. On the same vein $27(12.0 \%)$ of the teachers agreed. However, $5(2.0 \%)$ of the teachers were undecided, $23(10.0 \%)$ of the teachers disagreed whereas $15(6.5 \%)$ of the teachers strongly disagreed. On average, these findings generated a mean of $\mathrm{M}=4.174$, Std. Deviation $=$ 0.915. Majority, $170(74.5 \%)$ strongly agreed with the view that teachers' withdrawal from friendships has caused secondary school students' dismal performance. 39(17.0\%) of the teachers agreed. At the same time, $6(2.5 \%)$ of the teachers were undecided, $8(3.5 \%)$ of the teachers disagreed whereas $6(2.5 \%)$ of the teachers strongly disagreed. On average, these findings generated a mean of $\mathrm{M}=4.474$, Std. Deviation $=0.980$.

These findings lend credence to the findings of a study conducted in Hungary in which Piko (2006) established that job satisfaction was a negative predictor of each type of burnout subscale were withdrawn and thus had low levels of a sense of personal accomplishment. These findings further support the assertions of Gaylord et al (2013) posited that when socially withdrawn teachers do interact with peers, they appear to be less socially competent than typical teachers. These findings are also consistent with the findings of an observational study conducted in Germany in which Stewart and Rubin (2014) found that socially withdrawn teachers pursued lower-cost social goals and fewer high-cost social goals, and that their attempts to meet their social goals were less likely to succeed than those of their non-withdrawn age-mates. Hence, these findings point to the fact that having learned early that the expression of socially reticent behavior elicits peer rejection and victimization and some socially anxious teachers may mask their social qualms by expressing quite constructive and exploratory activity among peers which hinder their ability to deliver in their work. On the same breath, majority, 153(67.0\%) strongly agreed with the view that teachers rarely sympathize with their students which has negatively affected syllabus coverage. 26(11.5\%) of the teachers agreed. However, 13(5.5\%) of the teachers were undecided, $19(8.5 \%)$ of the teachers disagreed whereas $16(7.0 \%)$ of the teachers strongly disagreed. On average, these findings generated a mean of $\mathrm{M}=4.024$, Std. Deviation $=0.882$.

Majority, 171(75.0\%) strongly agreed with the view that teachers' unsympathetic attitude towards students has made them register low grades. $24(10.5 \%)$ of the teachers agreed. At the same time, $6(2.5 \%)$ of the teachers were undecided, $21(9.0 \%)$ of the teachers disagreed whereas $8(3.5 \%)$ of the teachers strongly disagreed. On average, these findings generated a mean of $\mathrm{M}=4.504$, Std. Deviation $=0.987$. These findings are consistent with the findings of a study conducted in Morocco in which Shaw and Emery (2015) posited that the shy, timid nature of socially withdrawn teachers may elicit the social perception of being easy targets. According to Shaw and Emery (2015), such teachers evoke victimization precisely because they present themselves as physically and emotionally weak and unlikely to retaliate. These findings point to the fact that, given that socially withdrawn teachers often experience peer rejection and victimization, it is not surprising that they feel and think poorly of themselves. This affirms the fact that persistent and pervasive nature of teachers' stress makes teaching a high stress occupation.

\subsection{Inferential Findings on the Influence of Teachers' Depersonalization on Implementation of Secondary School Curriculum}

However, to prove the possibility of the difference between teachers' depersonalization and implementation of secondary school curriculum, Data was collected on the number of teachers who have manifested instances of stress and students' academic performance in pre-national and national examinations and results are shown in Table 2:

\begin{tabular}{|c|c|c|}
\hline $\begin{array}{c}\text { Number of Teachers with Cases } \\
\text { of Stress }\end{array}$ & $\begin{array}{c}\text { Students' Performance in } \\
\text { Pre-National (\%) }\end{array}$ & $\begin{array}{c}\text { Students' Performance in } \\
\text { National Examinations (\%) }\end{array}$ \\
\hline 21 & 31.0 & 29.8 \\
\hline 17 & 40.0 & 47.0 \\
\hline 12 & 43.0 & 60.1 \\
\hline 9 & 50.0 & 66.5 \\
\hline 4 & 63.0 & 74.7 \\
\hline
\end{tabular}

Table 2: Results of the Number of Teachers with Reported Cases of Stress and

Students' Performance in Pre-National and National Examinations

Table 2 indicates that many secondary school teachers with reported cases of stress or depersonalization which has negatively influenced their students' academic performance in pre-national and national examinations. That is, the higher the number of teachers with cases of stress and are depersonalized, the lower the performance of secondary school students in pre-national and national examinations. These results further lend credence to the assertions of Stewart and Rubin (2014) who noted that stressed, depersonalized and socially withdrawn teachers pursued lower-cost social goals 
and fewer high-cost social goals, and that their attempts to meet their social goals were less likely to succeed than those of their non-withdrawn age-mates. These results were subjected to ANOVA at 95\% confidence level and the results of hypothesis testing are summarized on Table 3;

- Ho2: There is no significant influence of teachers' depersonalization on implementation of secondary school curriculum.

\begin{tabular}{|c|c|c|c|c|c|c|}
\hline \multicolumn{2}{|c|}{} & $\begin{array}{c}\text { Sum of } \\
\text { Squares }\end{array}$ & df & $\begin{array}{c}\text { Mean } \\
\text { Square }\end{array}$ & F & Sig \\
\hline \multicolumn{2}{|c|}{ Between People } & 678.956 & 4 & 169.739 & & \\
\hline \multirow{2}{*}{ Within People } & Between Items & 5051.681 & 2 & 2525.841 & 15.367 & .002 \\
\cline { 2 - 7 } & Residual & 1314.912 & 8 & 164.364 & & \\
\cline { 2 - 7 } & Total & 6366.593 & 10 & 636.659 & & \\
\hline \multicolumn{2}{|c|}{ Total } & 7045.549 & 14 & 503.254 & & \\
\hline
\end{tabular}

Table 3: ANOVA Analysis of the Difference between Means of the Number of

Teachers with Cases of Emotional Exhaustion and Students' Aca demic

Performance in Pre-National and National Examinations

Grand Mean $=37.8733$

The results from the ANOVA Statistics in Table 3 show that $F(2,4)=15.367$ and $p$-value $=0.002$. Since the $p$-value (0.002) is less than the pre-determined significance $(0.05)$, the Null Hypothesis, $\mathrm{H}_{0} 2$, is rejected. In other words, the alternative hypothesis, $\mathrm{H}_{1} 2$, which states that there was significant influence of teacher depersonalization on implementation of secondary school curriculum, is accepted. This indicates that the results were statistically significant and that there is significant difference between means of the number of secondary school teachers with reported cases of stress (depersonalization) and students' performance in pre-national and national examinations. This implies that stress amongst teachers in secondary schools is a major cause of incomplete syllabus coverage and dismal students' performance in pre-national and national examinations.

Besides, having learned early that the expression of socially reticent behavior elicits peer rejection and victimization and some socially anxious teachers may mask their social qualms by expressing quite constructive and exploratory activity among peers which hinder their ability to deliver in their work. In other words, emotional exhaustion and depersonalization scores increase as the recognition academics get for good work satisfaction scores decrease. Besides, depersonalization consists of cynical or negative attitudes about ones' clients. This dehumanizing perception of others can make secondary school teachers to view their students as deserving of their troubles.

4.3. Thematic Analysis of Qualitative Findings on the Influence of Teachers' Depersonalization on Implementation of Secondary School Curriculum

During interviews, the headmasters/ headmistresses and education officers also echoed similar sentiments. The interviewees also responded in favor of the view that teachers are always hostile towards students which have negatively affected syllabus coverage and affect their students' academic performance in pre-national and national examinations. One headmaster noted,

"In my school, sometimes, teachers appear hostile, harsh and quite indifferent towards students. Also, they lack the general desire to teach and cover their subject syllabi. They often appear annoyed and wronged from somewhere and this negatively affects the performance of students in pre-national and national examinations".

Just like in quantitative findings, these views further lend credence to the viewpoints held by Adem and Melek (2010) which established that the general burnout, emotional exhaustion and depersonalization scores increase as the recognition academics get for good work satisfaction scores decrease. One headmistress observed,

"Most teachers in my school always manifest signs of withdrawal, feel isolated, lonely and not willing to relate with their colleagues. They behave in a manner to show unwillingness to share their personal and work challenges which has impact on their teaching and translating into low grades amongst their students".

These views further corroborate the views expressed by Piko (2012) that job satisfaction was a negative predictor of each type of burnout subscale were withdrawn and thus had low levels of a sense of personal accomplishment. The interviewees also concurred with the assertions of Gaylord et al (2013) that when socially withdrawn teachers do interact with peers, they appear to be less socially competent than typical teachers. These views also attest to the fact that socially withdrawn teachers pursued lower-cost social goals and fewer high-cost social goals, and that their attempts to meet their social goals were less likely to succeed than those of their non-withdrawn age-mates. The interviewees also noted that the levels of empathy and sympathy amongst teachers towards their students' academic challenges are very low. One headmaster observed,

"Sometimes, teachers in my school manifest a tendency not to care or show concern towards their students' academic and personal problems. They rarely care whether they have done assignments or not or whether syllabus is covered adequately and students have mastered concepts in their subject areas".

These views further corroborate the views expressed by Shaw and Emery (2015) teachers who are socially withdrawn elicit the social perception of being easy targets. According to Shaw and Emery (2015), such teachers evoke victimization 
precisely because they present themselves as physically and emotionally weak and unlikely to retaliate. These findings point to the fact that, given that socially withdrawn teachers and young adolescents often experience peer rejection and victimization, it is not surprising that they feel and think poorly of themselves.

\section{Conclusions}

The study concludes that teacher depersonalization has a negative influence on teachers' ability to implement secondary school curriculum. It influences their willingness to cover syllabus and ensure that their students perform in internal and national examinations. From the study, it is evident that teachers always lose motivation towards syllabus coverage due to excessive burnout. Teachers under such teachers rarely complete their school syllabus nor do their students register impressive academic grades. Many secondary school teachers are often hostile, show no sympathy to students and are indifferent towards students and colleagues that in turn, influence syllabus coverage and academic performance of their students.

\section{Recommendations}

The study thus, recommends that teachers ought to develop positive self-esteem, attitude and positive perception towards oneself. They should attend counseling sessions to acquire techniques and mechanisms of coping with workloads and burnout. The Ministry of Education ought to hire more teachers to reduce teachers' workload from teachers who undertake up to 32 lessons to the required standard of 24 lessons per week. This may also reduce the class size from the current class size of up to 70 students to the required number of 45 students per class. This may also see a reduction on the time spent in co-curricular activities, administrative duties and attending to delegated functions, which create burnout amongst teachers. The Ministry of Education needs to increase the number and frequency of seminars and workshops for teachers and to remind them of their responsibilities and duties despite the heavy workload.

\section{References}

i. Adem, K. A. \& Melek, M. (2010). Shyness, teacher-child relationships, and socio-emotional adjustment in grade 1. International Journal of Behavioral Development, 34(3), 259-269.

ii. Bakker, A.B., \& Bal, D. E. (2010). The job demands-resources model: State of the art. Journal of Managerial Psychology, 22, 309-328.

iii. Beane, E. (2012). Use of Language Across the Public secondary schools' curriculum. London; Routledge.

iv. Bell, M., and Wolfe, C. (2014). Emotion and Cognition: An Intricately Bound Developmental Process," Child Development, Vol. 75, No. 2, 366-70.

v. Benner, A. D. (2010). The Cost of Teacher Turnover. Austin, Texas: Texas Center for Educational Research.

vi. Blase, J.J. (2013). A qualitative analysis of sources of teacher stress: Consequences for performance. American Educational Research Journal, 23, 13-40

vii. Cohen, D. \& Hill, H. (2012). Learning policy. London: Yale University Press.

viii. Cohen, J. (2011). Statistical power analysis for the behavioural sciences. Revised edition. Orlando, FL: Academic Press.

ix. Coplan, J. (2011). Early Language Milestone Scale: Examiner's Manual (Second edition). Austin, TX: Pro-ed.

x. Cordes, C. \& Dougherty, T.W. (2013). A review and an integration of research on job burnout. Academy of Management Review, 18 (4), 621-656.

xi. Corwin, R.G. (2013). Organizational reform and organizational survival: the teacher corps as an instrument of educational change. New York: Wiley.

xii. Cox, T. and Brockley, T. (2014). The experience and effects of stress in teachers. British Educational Research Journal. 10, 84.

xiii. David, J. (2015). The Persistent Burnout Theory. Job Burnout and Psychological Health

xiv. De Witt, M. (2013). The young child in context. Pretoria: Van Schaik.

xv. Eisenberg, N., Ehrenberg, R. G., Ehrenberg, R. A. and Rees, D. L. (2012). School district leave policies, absenteeism and student achievement. Journal of Human Resources. 26(1):72-105.

xvi. Gaylord, N., Kitzmann, K., \& Lockwood, R. (2013). Child characteristics as moderators of the association between family stress and pupils' internalizing, externalizing, and peer rejection. Journal of Child \& Family Studies, 12, 201.

xvii. Gazelle, S. \& Ladd, D. (2010). Child adaptation (pp. 96-161). New York: Wiley.

xviii. Gaziel, H. \& Rudolph, H. (2014). Coping with occupational stress among teachers: A cross-cultural study. Comparative Education, 29(1), 67-79.

xix. Gorman-Smith, D., Henry, D. \& Tolan, P. (2012). Exposure to community violence and violence perpetration: The protective effects of family functioning. Journal of education, 2(1);12-14

xx. Henderson, P. (2012). Innate and universal facial expressions: Evidence from developmental and disadvantaged toddlers to distress in age mates. Developmental Psychology, 21.

xxi. Kimani, P. J., Carrol, L., \& Mulu, J. (2012). A preliminary survey of counselling psychologists' personal experiences with depression and treatment. Professional Psychology: Research and Practice, 33, 402-407.

xxii. Kisthardt, W. E. (2011). The impact of the strengths model of case management from the consumer perspective. Washington, DC: American Psychiatric Association.

xxiii. Koon, J. R. (2012). Effects of expectancy, anxiety and task difficulty on teacher behavior. Syracuse University, Syracuse, New York: Unpublished Ph.D. Dissertation. University Microfilms71-18492, p.32. 
xxiv. Kyriacou, C., \& Sutcliffe, J. (2011). Teacher stress: Prevalence, sources, and symptoms. British Journal of Educational Psychology, 48, 159-167.

xxv. Ladd, A. J. (2011). Dialectical processes in develop-mental psychopathology. New York: Kluwer Academic/ Plenum.

xxvi. Lee, J., Lim, N., Yang, E., \& Lee, S. M. (2011). Antecedents and Consequences of Three Dimensions of Burnout in Psychotherapists: A Meta-Analysis. Professional Psychology: Research and Practice, 42(3), 252-258.

xxvii. Little, S. \& Garber, J. (2015). Aggression, depression, and stressful life events predicting peer rejection in pupils. Development \& Psychopathology, 7, 845 - 856.

xxviii. Miech, R. and Elder, G. H. (2011). The service ethic and teaching. Sociology of Education. 69:237-253.

xxix. Morris, P. (2012). Promoting curriculum reforms in the context of a political transition: an analysis of Hong Kongs' experience. Journal of Education Policy

xxx. Mwangi, D. (2012). Personal and interpersonal antecedents and consequences of victimization by peers. Journal of Personality and Social Psychology, 76, 677.

xxxi. Nash, R. J. (2010) The active mentor: Practical strategies for supporting new teachers. Thousand Oaks, CA: Sage Publication.

xxxii. Nelson, D. L. \& Simmons, B. L. (2011). Health psychology and work stress: A more positive approach'. Washington, DC: American Psychological Association, pp. 97-119.

xxxiii. Okoth, G. L. (2011). Effects of crime and violence in neighborhoods and schools on the behavior and performance of adolescents. Journal of Adolescent Research, 14.

xxxiv. Parker, P. D., Martin, A. J., Colmar, S., \& Liem, G. Q. (2012). Teachers' workplace wellbeing: Exploring a process model of goal orientation, coping behavior, engagement, and burnout. American Journal of Education 28 (4) 503513.

xxxv. Perry, B., Pollard, R., Blakley, T., Baker, W. (2014a). Maltreatment and vulnerability to depression. Development and Psychopathology, 4, 97-112.

xxxvi. Perry, N., Hutchinson, L., \& Thauberger, C. (2014b). Talking about teaching self-regulated learning: Scaffolding student teacher's development and use of practices that promote self-regulated learning. International Journal of Educational Research, 47(2), 97-108.

xxxvii. Rapp, J. T. (2011). Toward an empirical method for identifying matched stimulation for automatically reinforced behavior: A preliminary investigation. Journal of Applied Behavior Analysis, 39, 137-140.

xxxviii. Rowan, B., Corenti, R. and Richard, R. J. (2012). What Large Scale Research Tells Us about Teacher Effects on Student Achievement. Philadelphia: Consortium for Policy Research on Education, U. of Pennsylvania.

xxxix. Rubin, K. H., Bukowski, W. \& Parker, J. G. (2012). Peer interactions, relationships, and groups. New York: Wiley.

xl. Ryan, A. M. (2014). The peer group as a context for the development of young adolescent motivation and achievement. Child Development. 72(4): 35-50

xli. Shaw, D., \& Emery, R. (2015). Chronic family adversity and school-age pupils' adjustment. Journal of the American Academy of Child and Adolescent Psychiatry, 27, 200.

xlii. Shirom, A. (2013). A comparison of the construct validity of two burnout measures in two groups of professionals. International Journal of Stress Management 13, no. 2: 176-200.

xliii. Stewart, E. \& Rubin, N. (2014). Peer relations in maltreated pupils. Carlson New York: Appleton-Century-Crofts.

xliv. Vandenberghe, R., \& Huberman, A. M. (2011). Understanding and preventing teacher burnout: A sourcebook of international research and practice. New York, NY: Cambridge Press.

xlv. Wieck, K. (2010). Coping, stress and burnout in the South African Police Service in KwaZulu-Natal, South African Journal of Industrial Psychology, 29(3): 71-80.

xlvi. Wilson, S. (2011). Risk factors for teenage fatherhood. Journal of Marriage and the Family, 